УДК 349.3

\title{
ПРО СУТНІСТЬ ПОСЛУГИ СОЦАЛЬНОГО СУПРОВОДУ ВІДПОВІДНО ДО ЗАКОНОДАВСТВА УКРАЇНИ
}

\author{
С. Синчук \\ Львівський національний університет імені Івана Франка, \\ вул. Університетська, 1, Львів, Україна, 79000, \\ e-mail: synchuksvit@gmail.com
}

Статтю присвячено з'ясуванню законодавчої сутності соціальної послуги соціальний супровід, що надається особам (сім'ям), які належать до вразливих груп населення та/або перебувають у складних життєвих обставинах, і визначена нормами різних Законів України у сфрері соціального захисту громадян в Україні. Застосувавши порівняльний метод для з'ясування узгодженості правових норм, зроблено висновок про відсутність законодавчо-уніфікованого визначення соціального супроводу. Запропоновано відповідні зміни до законодавства.

Проаналізовано законодавчі дефініції поняття "соціальна послуга" та "соціальна робота". Доведено, що вони є тотожними за змістом та запропоновано узгодити їх нормативне використання.

Відзначено, що нормативна характеристика послуги соціальний супровід як базової, основної, комплексної насправді не характеризує їі специфіку, не вирізняє в системі соціальних послуг та не застосовується на практиці. Критично проаналізовано норми законодавства, які визначають зміст послуги соціального супроводу, наведено приклади невідповідності підзаконних нормативно-правових актів нормам Закону України "Про соціальні послуги" щодо дій, які формують зміст послуги соціальний супровід. Наголошено на необхідності нормативного визначення понять "соціальна опіка", "соціальна допомога", "соціальний патронаж” та уніфікованого їх упорядкування у соціальному законодавстві.

Ключові слова: соціальна робота, соціальна послуга, державний стандарт, соціальний патронаж, соціальна опіка.

DOI: http://dx.doi.org/10.30970/vla.2020.70.181

Соціальні послуги як вид соціального захисту осіб (сімей) в Україні так і не набули ефективного та якісного застосування на практиці. Важливим чинником, який призводить до такого стану, є недосконалість законодавства, що визначає зміст, обсяг, показники якості, умови та порядок надання кожної з передбачених Законом України "Про соціальні послуги" [8] послуг. Така невизначеність найбільше має значення щодо тих соціальних послуг, які на перший погляд $є$ зрозумілими для потенційних отримувачів, однак реалізувати їх (послуги) самостійно або ж знати, чого саме вимагати від надавачів цих послуг на практиці буває складно.

Теоретичні засади та алгоритм технології реалізації послуги соціального супроводу осіб (сімей), які належать до вразливих груп населення та (або) перебувають у складних життєвих обставинах, з огляду на вагоме значення цієї послуги у процедурі соціалізації їі отримувачів, є об’єктом наукового інтересу вчених соціально-педагогічного та психологічного спрямування дослідження. Натомість окремих правових розробок про соціальний супровід та його місце в системі соціального захисту осіб (сімей) в Україні дотепер немає. Тому видається за необхідне проаналізувати законодавчу сутність соціального супроводу в контексті ефективності та ясності для потенційного отримувача цієї соціальної послуги.

(C) Синчук С., 2020 
Соціальний супровід як один із видів базових соціальних послуг, що надають особам (сім'ям), які належать до вразливих груп населення та/або перебувають у складних життєвих обставинах, передбачено п. 8 ч. 6 ст. 16 Закону України "Про соціальні послуги" [81, абз. 3, 4 п. 2 ч. 5 ст. 17 Закону України "Про соціальну роботу 3 сім'ями, дітьми та молоддю" [9], абз. 21 ст. 1 Закону України "Про забезпечення організаційно-правових умов соціального захисту дітей-сиріт та дітей, позбавлених батьківського піклування" [5]. Однак змістовне визначення послуги соціального супроводу відповідно до кожного з названих нормативних актів є нетотожним.

Відповідно до Закону України “Про соціальні послуги”, соціальний супровід це дія, спрямована на профілактику складних життєвих обставин, подолання таких обставин або мінімізацію їх негативних наслідків для осіб/сімей, які в них перебувають (п. 17 ст. 1) [8]. Для подальшого дослідження важливо наголосити, що соціальні послуги $є$ видом не побутової, щоденної діяльності, а надаються надавачами на професійній основі (ч. 4 ст. 13) [8].

Відповідно до ст. 6-1 Закону України “Про соціальну роботу з сім'ями, дітьми та молоддю" соціальний супровід є одним із видів основної соціальної послуги, що надається сім'ям, дітям та молоді при здійсненні соціальної роботи [9]. Соціальна робота 3 сім'ями, дітьми та молоддю, згідно із абз. 4 ст. 1 зазначеного Закону України - це професійна діяльність, спрямована на запобігання, мінімізацію негативних наслідків та подолання складних життєвих обставин сімей, дітей та молоді, посилення їхньої здатності до реалізації власного життєвого потенціалу [9]. Абзацом 21 ст. 1 Закону України "Про забезпечення організаційно-правових умов соціального захисту дітей-сиріт та дітей, позбавлених батьківського піклування" соціальний супровід визначено як роботу, ...., яку проводять 3 метою подолання життєвих труднощів, збереження, підвищення їхнього соціального статусу [5].

Просте порівняння наведених законодавчих дефініцій соціальної послуги та соціальної роботи призводить до висновку про їхню змістовну тотожність. Тож професійна діяльність надавачів соціальних послуг у різних нормативних актах, які регулюють однаковий або суміжний вид відносин у сфері соціального захисту позначена різними законодавчими поняттями, що $є$ проявом неузгодженості норм законів, їх недоліком та потребує впорядкування.

Згідно із п. 11.3 Пропозицій до Класифікатора соціальних послуг з використанням видового поділу соціальних послуг у ч. 1 ст. 16 Закону України “Про соціальні послуги", соціальний супровід спрямований на сприяння подолання особою (сім'єю) складних життєвих обставин, є послугою соціальної підтримки [6]. Цікаво, що україномовне тлумачення слова “сприяння” має декілька значень, скориставшись якими, можна по-різному визначати сутність цільового спрямування об'єкта дослідження, а отже і трактувати зміст зобов'язання надавача послуги соціальний супровід у призмі задоволення соціальної потреби заявника: 1) створювати відповідні умови для здійснення, виконання і т. ін. чого-небудь; 2) подавати допомогу в чому-небудь; 3) створювати, викликати бажання виконувати якунебудь дію [1, с. 1377].

Незрозумілим у призмі правозастосовної доцільності $€$ визначення ст. 16 Закону України "Про соціальні послуги" соціальних послуг, зокрема і соціального супроводу як базових. Відповідно до п. 1 ст. 1 цього закону характеристика послуги як базової передбачає, що іiі надання забезпечується Київською та Севастопольською міськими державними адміністраціями, районними, районними у містах Києві та Севастополі державними адміністраціями, виконавчими органами міських рад міст обласного значення, виконавчими органами сільських, селищних, 
міських рад об'єднаних територіальних громад [8]. Однак жодна інша стаття Закону України "Про соціальні послуги" чи підзаконного нормативно-правового акту у цій сфері не містить переліку інших (небазових) видів соціальних послуг, не визначає специфіку надання саме базової послуги в системі інших (для прикладу тих, що надаються в межах муніципальної чи недержавних організаційно-правових форм), не впливає не індивідуальну/сімейну оплатність соціальної послуги.

Законом України “Про соціальну роботу з сім'ями, дітьми та молоддю” визначено, що соціальний супровід $є$ одним із видів основної соціальної послуги, що надається сім'ям, дітям та молоді при здійсненні соціальної роботи [9]. Водночас законодавством України не визначено ані специфіки, ані правових ознак, ані правових засад надання основних соціальних послуг.

Згідно 3 абз. 21 ст. 1 Закону України "Про забезпечення організаційноправових умов соціального захисту дітей-сиріт та дітей, позбавлених батьківського піклування" соціальний супровід - це робота, спрямована на здійснення соціальних опіки, допомоги та патронажу соціально незахищених категорій дітей та молоді 3 метою подолання життєвих труднощів, збереження, підвищення їхнього соціального статусу [5]. Рівночасно, відсутні норми права, які б встановлювали правові ознаки, умови, порядок надання соціальної опіки, допомоги й патронажу немає. Законодавець, пропонуючи юридичні терміни, не визначає їхнього зміст, що своєю чергою ускладнює їхнє розуміння у правозастосувальній та моніторинговій процедурі надання послуги соціального супроводу.

Законодавча дефініція соціального патронажу $є$ лише у п. 3 ст. 1 Закону України "Про соціальну адаптацію осіб, які відбувають чи відбули покарання у виді позбавлення волі або позбавлення волі на певний строк” [10]. Це допомога звільненим особам шляхом здійснення комплексу правових, економічних, організаційних, психологічних, соціальних та інших заходів, зокрема надання послуг, спрямованих на їхню соціальну адаптацію. Соціальна ж адаптація - це процес засвоєння особами соціального досвіду 3 метою повернення їх до самостійного загальноприйнятого соціально-нормативного життя в суспільстві [10]. А відповідно до п. 1 ст. 9 цього ж Закону України “суб’ єктами соціального патронажу надаються послуги тимчасового притулку, а також соціальні, медичні, юридичні, освітні, реабілітаційні та інші послуги" ‘10].

Провівши наукові паралелі між наведеними положеннями нормативних актів, бачимо, що соціальний патронаж як елемент послуги соціального супроводу відповідно до норм одного Закону України 「81 є комплексним поняттям, яке охоплює всі види соціальних послуг, що надаються особі відповідно до іншого [10]. Така хаотичність у використанні законодавчої термінології не сприяє єдності у правозастосовній практиці, ускладнює правореалізаційні процеси для пересічних громадян у повсякденній практиці, унеможливлює забезпечення єдності критеріїв у моніторингових процедурах щодо прав особи на конкретну соціальну послугу. У технології соціально-педагогічної роботи соціальний патронаж - це вид соціального обслуговування, який полягає у постійному соціальному нагляді, регулярному відвідуванні соціальним працівником житла отримувача послуги, наданні їм необхідної економічної, матеріально-побутової, лікувально-профілактичної допомоги [11].

Про неоднакове законодавче та наукове поняття "соціальна допомога" та необхідність упорядкування його застосування вже було розглянуто у науковій літературі [12, с. 393-416]. Сутність поняття "соціальна опіка" у соціальному законодавстві не визначено. Закон України "Про охорону дитинства" послуговується терміном “опіка і піклування” (абз. 4 ч. 1 ст. 5, ч. 5 ст. 13, ч. 8 ст. 19 і т. ін.) [7]. 
Детальний зміст послуги соціального супроводу сімей, у яких виховують дітей-сиріт і дітей, позбавлених батьківського піклування, що відповідає законодавчій дефініції, визначено Державним стандартом соціального супроводу сімей, у яких виховують дітей-сиріт та дітей, позбавлених батьківського піклування [2]. Це комплекс заходів, що передбачає допомогу у створенні та підтримці позитивного соціально-психологічного клімату в сім'ї, адаптацію дитини в нових умовах, створення належних умов для забезпечення індивідуальних потреб кожної дитинисироти та дитини, позбавленої батьківського піклування, у розвитку та вихованні, захист майнових, житлових та інших прав дитини, сприяння навчанню та розвитку дитини, допомогу у зміцненні/відновленні родинних та суспільно корисних зв'язків, у створенні та забезпеченні умов для пріоритетного права дитини на усиновлення, підготовку дитини до виходу із сім'ї, в тому числі до самостійного життя.

Пунктом 2 ч. 2 ст. 16 Закону України "Про соціальні послуги" соціальний супровід визначено як комплексну соціальну послугу [8]. Правові характеристики комплексності послуги соціального супроводу визначаємо із Пропозицій до Класифікатора соціальних послуг (Розділ 4) [6]. Зокрема, за зовнішньою формою вона $є$ узгодженими діями фахівців 3 надання постійної або систематичної комплексної допомоги особам/сім'ям, які перебувають у складних життєвих обставинах, розв'язати які шляхом надання простих соціальних послуг немає можливості. Згідно із п. 9 зазначених Пропозицій, усі комплексні соціальні послуги передбачають заходи 3 допомоги в аналізі життєвої ситуації отримувача комплексних соціальних послуг, визначенні його основних проблем, шляхів їх вирішення, складання плану виходу зі складної життєвої ситуації; надання інформації з питань соціального захисту населення. Всі ці заходи проводять із безпосереднім залученням отримувача комплексних соціальних послуг [6].

Варто відзначити, що, хоча в Законі України "Про соціальні послуги" соціальний супровід визначено як різновид соціальної послуги, у підзаконних актах, що супроводжують практичне застосування названого закону соціальний супровід визначають як щось інше, відокремлене від системи соціальних послуг. Такий висновок робимо вже із назви Порядку виявлення сімей (осіб), які перебувають у складних життєвих обставинах, надання їм соціальних послуг та здійснення соціального супроводу таких сімей (осіб) [4]. Аналогічні підтвердження $є$ у положеннях підзаконного акту (для прикладу, див п. 12, ч. 3 п. 27). Законодавча невизначеність щодо видової характеристики послуги соціального супроводу, на нашу думку, $є$ однією з причин нечіткості стандартів ії надання як виду соціального захисту особам (сім'ям), які належать до вразливих груп населення та (або) перебувають у складних життєвих обставинах, а отже, і моніторингу ефективності та якості їі надання.

Зміст соціального супроводу сімей (осіб), які перебувають у складних життєвих обставинах визначено Державним стандартом відповідної послуги. Це комплекс заходів, що передбачає: 1) оцінку потреб, 2) визначення шляхів вирішення основних проблем, 3) регулярні зустрічі чи відвідування отримувача послуги 3 метою моніторингу виконання поставлених завдань, 4) сприяння в отриманні інших послуг, 5) допомогу в усвідомленні значення дій та/або розвиток вміння керувати ними, 6) навчання та розвиток навичок, спрямованих на подолання чи мінімізацію складних життєвих обставин [3]. Таке трактування змісту послуги Державним стандартом соціального супроводу суперечить ч. 2 ст. 21 Закону України “Про соціальні послуги”, відповідно до якої рішення про надання чи відмову у наданні соціальних послуг приймають протягом 10 днів від дня одержання заяви, 
звернення, повідомлення про надання соціальних послуг за результатами оцінювання потреб особи/сім’ї у соціальних послугах. Відтак, послугу соціального супроводу надають лише у тому разі, якщо відповідна потреба особи/сім'ї встановлена та зафіксована як юридичний факт. Визначення шляхів вирішення основних потреб як складова послуги соціального супроводу, на нашу думку, є елементом п. 4 ч. 1 ст. 18 Закону України “Про соціальні послуги” розроблення індивідуального плану надання соціальних послуг. Зокрема, надання соціальних послуг, а отже і соціального супроводу, можливе шляхом ведення випадку, що охоплює декілька етапів, серед яких: 1) аналіз заяви/звернення про надання соціальних послуг, повідомлення про осіб/сім’ї, які перебувають у складних життєвих обставинах або в ситуаціях, що загрожують життю чи здоров'ю особи; 2) оцінювання потреб особи/сім’ї у соціальних послугах; 3) прийняття рішення про надання соціальних послуг 3 урахуванням індивідуальних потреб особи/сім’і; 4) розроблення індивідуального плану надання соціальних послуг; 5) укладення договору про надання соціальних послуг; 6) виконання договору про надання соціальних послуг та індивідуального плану надання соціальних послуг; 7) здійснення моніторингу надання соціальних послуг та оцінки їх якості (ч. 1 ст. 18 Закону України "Про соціальні послуги") [8].

Індивідуальний план $є$ основою для надання соціальної послуги та грунтується на результатах оцінки потреб отримувача соціальної послуги (п. 1 Розділу 4 Державного стандарту). Формулювання ще одного обов'язку надавача соціальної послуги як "регулярні зустрічі чи відвідування отримувача послуги з метою моніторингу виконання поставлених завдань” також викликає запитання, хто є суб'єктом надавачем послуги і кому саме були поставлені завдання.

Дещо інший зміст соціального супроводу запропоновано у Пропозиціях до Класифікатора соціальних послуг: консультування, допомога в усвідомленні значення дій та/або розвиток вміння керувати ними; навчання та розвиток навичок; психологічне консультування; психологічна підтримка, представництво інтересів; регулярні зустрічі/відвідування отримувача соціальної послуги [6].

I нарешті, ще один підзаконний акт, який визначає зміст послуги соціального супроводу, Порядок виявлення сімей (осіб), які перебувають у складних життєвих обставинах, надання їм соціальних послуг та здійснення соціального супроводу таких сімей (осіб), у п. 28 передбачено зміст соціальних послуг, що надає фахівець під час ведення соціального супроводу сім”і (особи), яка перебуває у складних життєвих обставинах. Водночас, перелік дій, які повинні бути вчинені під час соціального супроводу, диференціюються залежно від виду обставини: інвалідність, насильство в сім'ї, вживання психоактивних речовин, бездоглядність, відбуванням покарання у вигляді обмеження волі або позбавлення волі на певний строк, взяттям під варту одного з членів сім’ї (особи) та схильністю до правопорушень [6]. Тут знову ж простежуємо невідповідність підстав надання особі послуги соціального супроводу п. 15 ч. 1 Закону України "Про соціальні послуги”, де такий перелік значно ширший [8].

Неузгодженість і подекуди суперечність підзаконних нормативно-правових актів між собою та нормам Закону України "Про соціальні послуги" ускладнює правозастосовний процес у цій сфері та позбавляє його доступності для осіб (сімей), які й так перебувають у складних життєвих обставинах. Тому пропонуємо впорядкувати норми законодавства, що регулюють зміст та обсяг, норми і нормативи, умови та порядок надання та показники якості послуги соціальний супровід відповідно до ст. 17 Закону України "Про соціальні послуги" у єдиному підзаконному акті - Державному стандарті соціального супроводу. 
1. Великий тлумачний словник сучасної української мови / уклад. і голов. ред. В. Т. Бусел. Київ; Ірпінь: ВТФ «Перун», 2007. 1736 с.

2. Державний стандарт соціального супроводу сімей, у яких виховуються діти-сироти та діти, позбавлені батьківського піклування : наказ Міністерства соціальної політики України від 11 серпня 2017 № 1307. URL: https://zakon.rada.gov.ua/laws/show/z1089-17

3. Державний стандарт соціального супроводу сімей (осіб), які перебувають у складних життєвих обставинах, затверджений наказом Міністерства соціальної політики України від 31 березня 2016 № 318/ URL: https://zakon.rada.gov.ua/laws/show/z0621-16

4. Порядок виявлення сімей (осіб), які перебувають у складних життєвих обставинах, надання їм соціальних послуг та здійснення соціального супроводу таких сімей (осіб): Постанова Кабінету Міністрів України від 21 листопада 2013 р. № 896 // Офіційний Вісник України. 2013. № 98. Ст. 3609.

5. Про забезпечення організаційно-правових умов соціального захисту дітей-сиріт та дітей, позбавлених батьківського піклування : закон України від 13. січня 2005 р. № 2342-IV // Відомості Верховної Ради України. 2005. № 6. Ст. 147.

6. Пропозиції до Класифікатору соціальних послуг : офіційний сайт Міністерства соціальної політики України. URL: https://www.msp.gov.ua/news/16910.html?fbclid=IwAR0g8LQ99gIhXURaL59xrq9Z3_OzHw46Qdp_v3LUzRaacfGZhUcj0gAipCo

7. Про охорону дитинства: Закон України від 26 квітня 2001 р. № 2402-III // Відомості Верховної Ради України. 2001. № 30. Ст. 142

8. Про соціальні послуги: Закон України від 19 червня 2003 р. № 966-IV // Відомості Верховної Ради України. 2003. № 45. Ст. 358

9. Про соціальну роботу з сім’ями, дітьми та молоддю: Закон України від 21 червня 2001 № 2558-ІІІ // Відомості Верховної Ради України. 2001. № 42. Ст. 213.

10. Про соціальну адаптацію осіб, які відбувають чи відбули покарання у виді позбавлення волі або позбавлення волі на певний строк: Закон України від 20 січня 2018 р. № 2249VIII // Відомості Верховної Ради України. 2011. № 38. Ст. 380

11. Технології соціально-педагогічної роботи з сім'ями: навчально-методичний посібник / А. Й. Капська, І. В. Пєша, О. Ю. Міхеєва, М. Г. Соляник. Київ: Слово, 2015. 328 с. Розділ: Соціальний патронаж. URL: https://pidruchniki.com/78684/sotsiologiya/sotsialniy_patronazh

12. Synczuk S. M. Zagadnienia teoretyczne dotyczące uzasadnienia cech prawnych pomocy społecznej w dzedzinie pomocy społecznej na Ukrainie / S. M. Synczuk // WrocławskoLwowskie zeszyty prawnicze. Wrocław Wydawnictwo Uniwersytetu Wrocławskiego, 2012. S. 393-416.

\section{References}

1. Velykyj tlumachnyj slovnyk suchasnoi ukrains'koi movy. (2007). / uklad. i holov. red. V. T. Busel. Kyiv; Irpin' : VTF "Perun”, 1736 s.

2. Derzhavnyj standart sotsial'noho suprovodu simej, u iakykh vykhovuiut'sia dity-syroty ta dity, pozbavleni bat'kivs'koho pikluvannia: nakaz Ministerstva sotsial'noi polityky Ukrainy vid 11 serpnia 2017 № 1307 Retrieved from https://zakon.rada.gov.ua/laws/show/z1089-17

3. Derzhavnyj standart sotsial'noho suprovodu simej (osib), iaki perebuvaiut' u skladnykh zhyttievykh obstavynakh, zatverdzhenyj nakazom Ministerstva sotsial'noi polityky Ukrainy vid 31 bereznia 2016 № 318 Retrieved from: https://zakon.rada.gov.ua/laws/show/z0621-16

4. Poriadok vyiavlennia simej (osib), iaki perebuvaiut' u skladnykh zhyttievykh obstavynakh, nadannia im sotsial'nykh posluh ta zdijsnennia sotsial'noho suprovodu takykh simej (osib): 
postanova Kabinetu Ministriv Ukrainy vid 21 lystopada 2013 r. № 896. (2013). Ofitsijnyj Visnyk Ukrainy, - № 98, St. 3609.

5. Pro zabezpechennia orhanizatsijno-pravovykh umov sotsial'noho zakhystu ditej-syrit ta ditej, pozbavlenykh bat'kivs'koho pikluvannia : zakon Ukrainy vid 13. sichnia 2005 r. № 2342-IV. (2005). Vidomosti Verkhovnoi Rady Ukrainy, № 6, St. 147.

6. Propozytsii do Klasyfikatoru sotsial'nykh posluh: ofitsijnyj sajt Ministerstva sotsial'noi polityky Ukrainy Elektronnyj resurs Retrieved from https://www.msp.gov.ua/news/16910.html?fbclid=IwAR0g8LQ99gIhXURaL59xrq9Z3_OzHw46Qdp_v3LUzRaacfGZhUcj0gAipCo

7. Pro okhoronu dytynstva: Zakon Ukrainy vid 26 kvitnia 2001 r. № 2402-III. (2001). Vidomosti Verkhovnoi Rady Ukrainy, № 30, St. 142

8. Pro sotsial'ni posluhy: Zakon Ukrainy vid 19 chervnia 2003 r. № 966-IV. (2003). Vidomosti Verkhovnoi Rady Ukrainy, № 45, St. 358

9. Pro sotsial'nu robotu z sim'iamy, dit'my ta moloddiu: Zakon Ukrainy vid 21 chervnia 2001 № 2558-III. (2001). Vidomosti Verkhovnoi Rady Ukrainy, № 42, St. 213.

10. Pro sotsial'nu adaptatsiiu osib, iaki vidbuvaiut' chy vidbuly pokarannia u vydi pozbavlennia voli abo pozbavlennia voli na pevnyj strok: Zakon Ukrainy vid 20 sichnia 2018 r. № 2249-VIII. (2011). Vidomosti Verkhovnoi Rady Ukrainy, № 38, St. 380

11. Tekhnolohii sotsial'no-pedahohichnoi roboty z sim'iamy: navchal'no-metodychnyj posibnyk / A. J. Kaps'ka, I. V. Piesha, O. Yu. Mikheieva, M. H. Solianyk. KYIV: Slovo, 2015. 328 s. Rozdil: Sotsial'nyj patronazh. Elektronnyj resurs Retrieved from https://pidruchniki.com/78684/sotsiologiya/sotsialniy_patronazh

12. Synczuk, S. M. (2012). Zagadnienia teoretyczne dotyczące uzasadnienia cech prawnych pomocy społecznej w dzedzinie pomocy społecznej na Ukrainie / S. M. Synczuk. WrocławskoLwowskie zeszyty prawnicze. Wrocław Wydawnictwo Uniwersytetu Wrocławskiego, 393-416.

\title{
ON THE ESSENCE OF THE SOCIAL SUPPORT SERVICE UNDER UKRAINIAN LEGISLATION
}

\author{
S. Synchuk \\ Ivan Franko National University of Lviv, \\ 1, Universytetska Str., Lviv, Ukraine, 79000, \\ e-mail:synchuksvit@gmail.com
}

The article regards the place of social support service, provided to a person (family) belonging to vulnerable groups and/or who are in difficult life circumstances, defined by the norms of different Laws of Ukraine, in the sphere of social security of Ukrainian citizens. Following on from applying the comparative method to find out the consistency of legal norms, the author stresses that there is no legally unified definition of social support. The author highlights legislative contraventions on the determination of the place of social support in the system of social security types of Ukrainian citizens as well as on the characteristics of social support as a type of social service. The researcher suggests the amendments to the legislation. The author emphasizes that the normative consolidation of the social support service as a service of social assistance does not determine its legal specificity with respect to other types of professional social protection activities.

Legislative definitions of "social service" and "social work" are analyzed in this article. The author proves that these terms are identical in content, and the research proposes to harmonize their regulatory use.

Specific attention is paid to the fact that the normative characteristics of the social support service as basic service does not characterize its specifics, does not distinguish it in the 
system of social services and is not applied in practice. The researcher also argues that the legislation on social security does not contain the list of other (not basic) types of social services, does not determine the specifics of providing the basic service in the system of others, does not affect the individual / family availability of payment of the social service. The author stresses that the characteristic of social support service as a basic service is a legislative declaration and has no application in practice.

Social care, social assistance and social patronage are the elements that determine the legislative content of the social support service of vulnerable groups of kids and young people. At the same time, the current legislation does not establish the legal features that characterize these notions, does not define the legal conditions for the provision of each of the components of the social service.

The researcher critically analyses legal norms that define the list of professional actions that shape the content of the social support service of a person (family) and the legal grounds for its provision. The author lists a number of examples of inconsistencies between by-laws and provisions of the Law of Ukraine "On Social Services".

The researcher emphasizes the necessity to streamline the rules of legislation governing the content and scope, rules and regulations, conditions and procedure of providing and indicators of quality of social support service in a sole by-law - The State Standard of Social Support.

Keywords: social work, social security, state standard, social patronage, social care.

Стаття: надійшла до редакції 01.05.2020 прийнята до друку 12.06.2020 